\title{
Analysis of the Structure and Diversity of Prosopis africana (G. et Perr.) Taub. Tree Stands in the Southeastern Niger
}

\author{
Laouali Abdou ${ }^{1}$, Boubé Morou ${ }^{2}$, Tougiani Abasse ${ }^{3} \&$ Ali Mahamane ${ }^{1,4}$ \\ ${ }^{1}$ Université de Diffa, Faculté des Sciences Agronomiques, BP 78, Diffa, Niger \\ ${ }^{2}$ Université Dan Dicko Dankoulodo de Maradi, Faculté des Sciences et techniques, Département de Biologie, BP \\ 465, Maradi, Niger \\ ${ }^{3}$ Institut National de Recherche Agronomique du Niger, BP 429, Niamey, Niger \\ ${ }^{4}$ Université Abdou Moumouni, Faculté des Sciences et Techniques, Département de Biologie, Laboratoire Garba \\ Mounkaila, BP 10662, Niamey, Niger \\ Correspondence: Laouali Abdou, Université de Diffa, Faculté des Sciences Agronomiques, BP 78, Diffa, Niger. \\ E-mail: abdoulaouali2000@yahoo.fr
}

Received: February 2, 2016 Accepted: February 26, 2016 Online Published: February 29, 2016

doi:10.5539/jps.v5n1p58 URL: http://dx.doi.org/10.5539/jps.v5n1p58

\begin{abstract}
All parts of Prosopis africana are used by rural people in Niger, and this exposes it to degradation and a regeneration problems. The objective of this study was to determine the structure and regeneration of $P$. africana stands in the southern regions of Maradi and Zinder, Niger. Data were collected in plots, following transects after stratified sampling. Trunk diameter of all woody species was recorded in 126 plots. The diversity was analyzed and diameter structure and regeneration rates were determined. P. africana was the predominant species in both Maradi and Zinder: frequency $=40.35 \%$ and $43.95 \%$ of all species, respectively in Maradi and Zinder; importance value index $=40.57 \%$ in Maradi and $48.60 \%$ in Zinder. The Shannon diversity index was 2.82 in Maradi and 2.40 in Zinder and the Sorensen similarity index between the two regions was 0.73 . According to the diameter structure, the stands were degraded in Zinder but regenerating in Maradi. The density of P. africana per hectare for trees with trunk diameter $\geq 5 \mathrm{~cm}$ and $<5 \mathrm{~cm}$, respectively was 16 and 51 in Maradi, and 30 and 12 in Zinder. The regeneration rate of $P$. africana was low compared with the general woody population. These results show the need for reforestation operations, using appropriate techniques, to avoid local extinction of the species.
\end{abstract}

Keywords: Prosopis africana, tree stand, structure, degradation, regeneration, Niger

\section{Introduction}

In the Sahel in general and in Niger in particular, trees provide many products and services to rural populations (Larwanou et al., 2010; Laouali et al., 2014), which exposes them to high anthropogenic pressure reducing their natural regeneration. As a result, many populations of woody species are in a regressive dynamics characterized by the increasing scarcity or lack of younger individuals (Endress et al., 2006; Bellefontaine et al., 2010; Sanogo et al., 2013). The exploitation and marketing of non-timber forest products in Africa to date are primarily designed to increase gatherers' individual incomes without concern for sustainable management. Sustainable management would require ensuring natural regeneration of the species, and promoting their domestication to reduce the pressure on natural populations (Ouédraogo et al., 2006). Prosopis africana is a particularly vulnerable species because all parts of the tree are used by rural communities (Faye et al., 2011). Its wood is dense (Sotelo Montes \& Weber, 2009) and highly resistant, so it is used for making construction poles and planks, and mortars and pestles. The wood has a high calorific value (Sotelo Montes et al., 2011), so it is highly valued for charcoal by blacksmiths. The leaves, roots and especially the barkare used in traditional medicine. The leaves and pods are used for fodder and the seeds for food (Larwanou, 1994; Arbonnier, 2000; Agboola, 2004; Larwanou et al., 2012; Laouali et al., 2014). Unfortunately, this species is facing a regeneration problem (Ahoton et al., 2009, Niang-Diop et al., 2010; Laouali et al., 2015) and overexploitation to which are added climatic conditions increasingly difficult due to climate change. This will result in a regression of the species' population or its disappearance if sustainable management precautions are not taken.

In Niger, $P$. africana is represented by scattered individuals with some relic stands in the southern regions of 
Dosso, Maradi and Zinder. Little information is available on their structure and regeneration. It is therefore necessary to have reliable data on the current state of these stands for better conservation and sustainable management of the species.

The main objective of this study is to characterize the P. africana tree stands in the southeastern Niger on based on the analysis of their structure and diversity.

\section{Material and Methods}

\subsection{Study Area}

The study was conducted in the southern regions of Maradi and Zinder (Figure 1). Relevant administrative departments are Gazaoua in Maradi region, Kantché and Magaria in Zinder region. The human population in the Aguié and Gazaoua departments (which formed the same department) expanded from 172,922 to 406,532 inhabitants or from 57.52 to 135.24 inhabitants / $\mathrm{km}^{2}$ from 1988 to 2012. The human population in the Kantché and Magaria departments expanded from 518,452 to 976,924 inhabitants or from 82.95 to 156.3 inhabitants / $\mathrm{km}^{2}$ from 1988 to 2012 (Institut National de la Statistique/Niger [INS], 2014). The socio-economic activities of these populations are dominated by agriculture, livestock, crafts, trade. The climate is sahelo-soudanian. In the south of Maradi, the average annual temperature is around $28^{\circ} \mathrm{C}$. The average annual rainfall from 1981 to 2010 at the Gazaoua station was $446.32 \mathrm{~mm}$. The soils are mainly dunal and the flora is dominated by species in the Mimosaceae family (Prosopis africana (Guill. \& Perr.) Taub., Albizia chevalieri Harms, Faidherbia albida (Del.) Chev....), the Caesalpiniaceae family (Piliostigma reticulatum (DC.) Hochst., Cassia singueana (Del.) Lock, Bauhinia rufescens Lam....), the Combretaceae family (Combretum glutinosum Perr., Guiera senegalensis J. F. Gmel, Anogeissus leiocarpa (DC.) Guill. \& Perr. ...) and the Anacardiaceae family (Sclerocarya birrea (A. Rich.) Hochst., Lannea microcarpa Engl. \& K. Krause ...). In the south of Zinder, the average annual rainfall is around $525 \mathrm{~mm}$. The average temperature is $22.5^{\circ} \mathrm{C}$. The soils are mainly sandy, loamy sand and clay loam. The flora is dominated by the Mimosaceae (Faidherbia albida (Del.) Chev., Prosopis africana (Guill. \& Perr.) Taub.) and the Anacardiaceae (Lanea microcarpa Engl. \& K. Krause) (United States Agency for International Development [USAID], 2006; Laouali et al., 2014). Each of these areas is shared between the central south sahelian and central north soudanian compartments, according to Saadou (1990) phytogeographic subdivisions on the basis of climatic conditions; the vegetation consists of Combretum thickets, steppes, lowland dry forests, gallery forests and savannas.

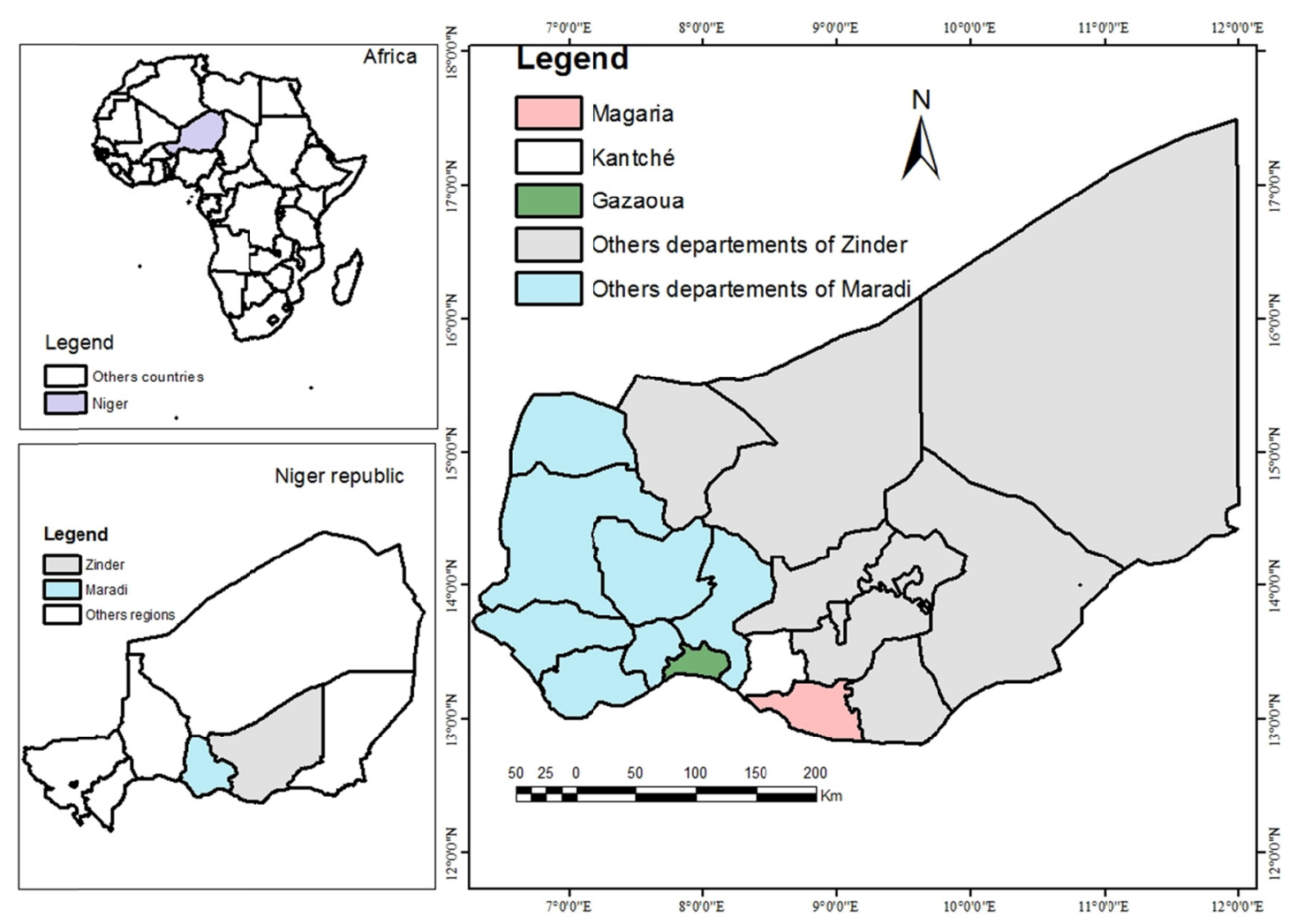

Figure 1. Location of the study area 


\subsection{Sampling}

The sampling, guided by the presence of $P$. africana in the regions and administrative departments, was systematic across transects in the territories of villages. In the Gazaoua administrative department in the Maradi region, sampling was conducted in three villages (Elguéza, Guidan Adamou and Dan Damou). In the Zinder region, the surveys were conducted in eight villages (Bawada, Angoual kirya, Sabar, Gagéré, Kahin baka, Kadeye, Kokotaou and Tsagai) distributed in the Kantché and Magaria administrative departments. The administrative departments were selected after a field visit and a consultation of resource persons which allowed having more information about the presence of the species. Villages were selected following recommendations from the departmental offices of the Ministry of Environment.

The P. africana stands were identified prior to sampling. Different sampling schemes were used in the two regions because stand structure differed. In the Maradi region, the only one stand of $P$. africana studied was homogeneous and extended throughout the three village territories. In the Zinder region, there were many stands located in the village territories, and the stands were not contiguous. In the Maradi region, individuate plots (50 x $50 \mathrm{~m}$ ) were arranged in seven linear and parallel sampling strategies (transects) with a length of $4 \mathrm{~km}$ each and separated by one $\mathrm{km}$, individuated using a GPS. In each sampling strategy, there was a distance of $400 \mathrm{~m}$ between plots. A total of 62 plots were surveyed, and these covered the entire P. africana stand. Plots size is justified by the fact that the studied stands are parklands and the selected layout allowed reaching a sampling rate of $1.8 \%$. In the Zinder region, plots $(50 \times 50 \mathrm{~m})$ were placed along four sampling strategies (with a length of 1.5 $\mathrm{km}$ each) that extended radially in four directions (compass directions) from each village. A total of 64 plots distributed among the eight villages were surveyed.

\subsection{Data Collection}

Data collected during the inventory are including the number of individuals for each woody species, tree height, crown diameter and stem diameter at breast height. Data were recorded only for individuals with a trunk diameter $\geq 5 \mathrm{~cm}$. Trees with trunk diameter $<5 \mathrm{~cm}$ were considered young natural regeneration: these trees were counted.

\subsection{Diversity and Species Importance Value Indices}

To analyze the diversity between regions and inside regions, several indices were calculated.

The diversity index of Shannon and Weaver (1949) was calculated to study the Alpha diversity for assessing the weight of the species in land use in each region. This index varies depending on the number of species present. It is higher when there are more species, indicating greater diversity. It is calculated as bits per individual and its formula is:

$$
H=-\sum_{i=1}^{s} p i \log _{2} p i
$$

$S=$ total number of species and $p i=$ relative frequency of species. Pielou evenness index was also calculated. Its formula is:

$$
E=\frac{H}{H \max } \text { where } \operatorname{Hmax}=\log _{2} S
$$

$S$ is the total number of species. The Pielou evenness index varies between 0 and 1 . It is 0 when there is a phenomenon of dominance and 1 when the distribution of individuals among species is homogenous.

The coefficient of Sorensen (1948) was calculated to assess beta diversity for comparing habitats of the two regions. This index expresses the degree of similarity between two sites and has the formula:

$$
\text { Is }=\frac{2 C}{2 C+A+B}
$$

$A$ is the number of species found only in site $1 ; B$ is the number of species found only in site 2 , and $C$ is the number of species common to both sites. Beta diversity is the importance of species replacement or biotic change along environmental gradients. The interest of its study is to highlight the diversity across the region.

To appreciate the importance of tree species in general and that of $P$. africana in particular at the study regions, the importance value index (IVI) (Curtis \& Macintosh, 1951) was calculated. This index is expressed by the formula:

$$
\text { IVI }(\%)=\text { relative density }+ \text { relative dominance }+ \text { relative frequency (for the species) }
$$


The relative dominance of one species (relative basal area) is the quotient of its basal area per total basal area of all species. The relative density of a species is the ratio between its absolute density and total absolute densities of all species multiplied by 100 . The relative frequency of a species is the ratio between its specific frequency and the total specific frequencies of all the species multiplied by 100 .

Basal area was calculated using the following formula:

$$
G\left(m^{2} / h a\right)=\frac{\pi}{40000 s} \sum_{i=1}^{n} d i^{2}
$$

$d$ is the trunk diameter $(\mathrm{cm})$ of the tree $i$ in the plot and $s$ the area of the plot (ha). The trees were then divided into 18 diameter classes of $5 \mathrm{~cm}$. Furthermore, to better analyze the data, the observed structure was modeled using the parameters of the theoretical Weibull distribution whose probability density function is (Rondeux, 1999):

$$
f(x)=\frac{c}{b}\left(\frac{x-a}{b}\right)^{c-1} \exp \left[-\left(\frac{x-a}{b}\right)^{c}\right]
$$

$x$ is the trunk diameter of the tree; $f(x)$ is the probability density value at point $x . a$ is the position parameter: it is 0 if all categories of trees are considered (from plantlets to the seed trees) during the inventory; it is not null if the trees have a diameter $\geq a$ ( $a=5$ in this study). $b$ is the scale parameter, linked to the central value of the probability distribution of variable $x=$ diameter. $c$ is the shape parameter related to the diameter structure. A value of $\mathrm{c}<1$, distribution "inverted $\mathrm{J}$ " is characteristic of multispecies or uneven-aged stands, while $\mathrm{c}>3.6$ is characteristic of predominantly aged individuals stands. Moreover, $1<\mathrm{c}<3.6$ means stands with predominance of young individuals or small diameter. Minitab 16 software was used for this purpose. To test the adjustment of the structure observed in the Weibull distribution, a log-linear analysis was applied with the R 2.15.3 software. This structure determination concerns the total woody population on one hand and $P$. africana the other hand. To appreciate the regeneration, the density of adult trees and that of the young individuals were calculated for both the total woody population and $P$. africana, which were used to calculate the regeneration rates. The results were compared through a FISHER test performed with the Minitab 16 software. Thus, the regeneration rate of $P$. africana and that of the woody population were compared in each region. A comparison was also made between $P$. africana regeneration rates of the two regions and between the woody population regeneration rates of the two regions.

\section{Results}

\subsection{Diversity Analysis}

Values for Shannon diversity index $(\mathrm{H})$, maximum diversity $(\mathrm{H}$ max) and Pielou evenness index (E) in the two regions are listed in Table 1.Diversity was relatively low compared to the maximum diversity at both regions. There was no significant difference in diversity and evenness between the Maradi and Zinder regions $(\mathrm{P}>0.05)$. The value of the Sorensen similarity index is 0.73 .

Table 1. Diversity and equitability indexes values

\begin{tabular}{llll}
\hline Region & H & Hmax & E \\
\hline Maradi & 2.82 & 4.70 & 0.60 \\
Zinder & 2.40 & 4.52 & 0.53 \\
\hline
\end{tabular}

\subsection{Dendrometric Characteristics and Regeneration}

The inventories included 26 woody species in Maradi (Table 2) and 23 woody species in Zinder (Table 3). $P$. africana had the largest IVI at both regions: $121.72 \%$ (40.57\% of the total IVI) in Maradi, and $145.79 \%(48.60 \%$ of the total IVI) in Zinder. 
Table 2. Dendrometric parameters of species recorded in the Maradi region

\begin{tabular}{|c|c|c|c|c|}
\hline Species & RF (\%) & RDs (\%) & RDm (\%) & IVI (\%) \\
\hline Prosopis africana (Guill. \& Perr.) Taub. & 40.35 & 40.35 & 41.02 & 121.72 \\
\hline Piliostigma reticulatum (DC.) Hochst. & 22.65 & 22.65 & 26.28 & 71.59 \\
\hline Faidherbia albida (Del.) Chev. & 14.08 & 14.08 & 14.94 & 43.09 \\
\hline Albizia chevalieri Harms & 1.88 & 1.88 & 3.66 & 7.41 \\
\hline Bauhinia rufescens Lam. & 3.35 & 3.35 & 0.42 & 7.12 \\
\hline Dichrostachys cinerea (L.) Wight \& Arn. & 2.95 & 2.95 & 0.27 & 6.17 \\
\hline Diospyros mespiliformis Hochst. ex A. Rich. & 1.34 & 1.34 & 2.62 & 5.31 \\
\hline Hyphaene thebaica (L.) Mart. & 1.74 & 1.74 & 1.70 & 5.19 \\
\hline Lannea microcarpa Engl. \& K. Krause & 0.94 & 0.94 & 2.26 & 4.14 \\
\hline Balanites aegyptiaca (L.) Del. & 1.61 & 1.61 & 0.71 & 3.93 \\
\hline Azadirachta indica A. Juss. & 1.61 & 1.61 & 0.53 & 3.75 \\
\hline Tamarindus indica $\mathrm{L}$. & 0.40 & 0.40 & 2.47 & 3.28 \\
\hline Annona senegalensis Pers. & 1.47 & 1.47 & 0.03 & 2.98 \\
\hline Pterocarpus erinaceus Poir. & 0.40 & 0.40 & 2.04 & 2.85 \\
\hline Acacia nilotica (L.) Willd. ex Del. subsp. Nilotica & 0.94 & 0.94 & 0.64 & 2.52 \\
\hline Guiera senegalensis J. F. Gmel & 0.94 & 0.94 & 0.02 & 1.90 \\
\hline Combretum glutinosum Perr. & 0.67 & 0.67 & 0.03 & 1.37 \\
\hline Cassia singueana (Del.) Lock & 0.54 & 0.54 & 0.00 & 1.08 \\
\hline Strychnos innocua Del. & 0.40 & 0.40 & 0.18 & 0.99 \\
\hline Maerua oblongifolia (Forssk.) A. Rich. & 0.40 & 0.40 & 0.01 & 0.81 \\
\hline Moringa oleifera Lam. & 0.40 & 0.40 & 0.00 & 0.81 \\
\hline Sclerocarya birrea (A. Rich.) Hochst. & 0.27 & 0.27 & 0.07 & 0.60 \\
\hline Calotropis procera (Ait.) Ait. f. & 0.27 & 0.27 & 0.00 & 0.54 \\
\hline Vitex doniana Sweet & 0.13 & 0.13 & 0.07 & 0.34 \\
\hline Maerua angolensis DC. & 0.13 & 0.13 & 0.00 & 0.27 \\
\hline Ziziphus mauritiana Lam. & 0.13 & 0.13 & 0.00 & 0.27 \\
\hline Total: 26 & 100 & 100 & 100 & 300 \\
\hline
\end{tabular}

Note. $\mathrm{RF}=$ Relative frequency; RDs = Relative density; RDm = Relative dominance; IVI = Importance value index. 
Table 3. Dendrometric parameters of species recorded in the Zinder region

\begin{tabular}{|c|c|c|c|c|}
\hline Species & RF (\%) & RDs (\%) & $\operatorname{RDm}(\%)$ & IVI (\%) \\
\hline Prosopis africana (Guill. \& Perr.) Taub. & 43.95 & 43.95 & 57.89 & 145.79 \\
\hline Faidherbia albida (Del.) Chev. & 32.58 & 32.58 & 22.69 & 87.86 \\
\hline Sclerocarya birrea (A. Rich.) Hochst. & 4.24 & 4.24 & 4.88 & 13.37 \\
\hline Tamarindus indica $\mathrm{L}$. & 2.80 & 2.80 & 3.61 & 9.20 \\
\hline Combretum glutinosum Perr. & 2.62 & 2.62 & 0.66 & 5.90 \\
\hline Annona senegalensis Pers. & 2.62 & 2.62 & 0.12 & 5.35 \\
\hline Lannea microcarpa Engl. \& K. Krause & 1.71 & 1.71 & 1.58 & 5.01 \\
\hline Parkia biglobosa (Jacq.) R. Br. Ex G. Don & 1.08 & 1.08 & 2.82 & 4.98 \\
\hline Albizia chevalieri Harms & 1.71 & 1.71 & 1.51 & 4.94 \\
\hline Guiera senegalensis J. F. Gmel & 2.17 & 2.17 & 0.01 & 4.34 \\
\hline Dichrostachys cinerea (L.) Wight \& Arn. & 1.17 & 1.17 & 0.32 & 2.67 \\
\hline Piliostigma reticulatum (DC.) Hochst. & 0.81 & 0.81 & 0.59 & 2.21 \\
\hline Adansonia digitata $\mathrm{L}$. & 0.27 & 0.27 & 0.84 & 1.38 \\
\hline Daniellia oliveri (Rolfe) Hutch. \& Dalz. & 0.18 & 0.18 & 0.76 & 1.12 \\
\hline Terminalia avicennioides Guill. \& Perr. & 0.36 & 0.36 & 0.33 & 1.05 \\
\hline Balanites aegyptiaca (L.) Del. & 0.27 & 0.27 & 0.35 & 0.89 \\
\hline Ficus platyphylla Del. & 0.09 & 0.09 & 0.63 & 0.81 \\
\hline Ziziphus mauritiana Lam. & 0.36 & 0.36 & 0.07 & 0.79 \\
\hline Bauhinia rufescens Lam. & 0.27 & 0.27 & 0.02 & 0.56 \\
\hline Azadirachta indica A. Juss. & 0.18 & 0.18 & 0.19 & 0.55 \\
\hline Cassia singueana (Del.) Lock & 0.27 & 0.27 & 0.00 & 0.54 \\
\hline Hyphaene thebaica (L.) Mart. & 0.18 & 0.18 & 0.10 & 0.46 \\
\hline Acacia nilotica (L.) Willd. Ex Del. Subsp. Nilotica & 0.09 & 0.09 & 0.03 & 0.21 \\
\hline Total: 23 & 100 & 100 & 100 & 300 \\
\hline
\end{tabular}

The density was higher in Zinder than Maradi for trees $\geq 5 \mathrm{~cm}$ in trunk diameter. Trees $<5 \mathrm{~cm}$ in trunk diameter were more common in Maradi (Table 4). This concerns woody population one hand and P. africana on the other hand.

Tableau 4. Woody population and $P$. africana density at both regions for trees $\geq 5 \mathrm{~cm}$ and $<5 \mathrm{~cm}$ in trunk diameter

\begin{tabular}{lccccccc}
\hline Regions & \multicolumn{9}{c}{ Density (trees/ha) } \\
\hline & \multicolumn{3}{c}{ Woody population } & \multicolumn{3}{c}{ P. africana } \\
Maradi & $\geq 5 \mathrm{~cm}$ & $<5 \mathrm{~cm}$ & Total & 16 & $<5 \mathrm{~cm}$ & Total \\
Zinder & 41 & 143 & 184 & 30 & 12 & 67 \\
\hline
\end{tabular}

Assuming that trees with trunk diameter $\leq 5 \mathrm{~cm}$ reflect relatively recent natural regeneration, the regeneration rate was significantly higher in Maradi than in Zinder $(\mathrm{P}<0.05)$, for both the woody population and for $P$. africana. For the regions separately, the regeneration rate of $P$. africana was significantly lower than that of woody population in Zinder $(\mathrm{P}<0.05)$, but these two rates were not significantly different in Maradi $(\mathrm{P}=0.209)$ (Figure 2). 


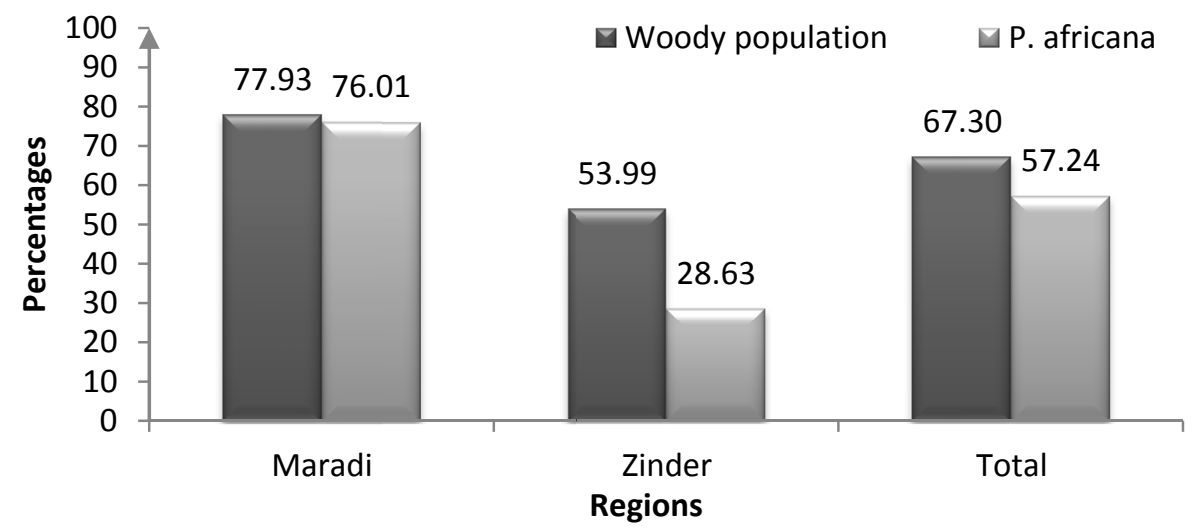

Figure 2. Regeneration rates of woody population and P. africana in Maradi, Zinder and both regions

\subsection{Structure of Woody Population}

The mean trunk diameter of $P$. africana was significantly higher in Zinder $(38.13 \pm 8.78 \mathrm{~cm})$ than in Maradi $(17.8 \pm 13.6)(\mathrm{P}<0.001)$. The distribution of trees in diameter classes in Maradi had a "reversed J" shape. It fit the theoretical Weibull distribution with shape parameter $\mathrm{c}=0.93$ for woody population and $\mathrm{c}=0.82$ for $P$. africana (Figure 3a and 3b). In Zinder, the distribution of trees in diameter classes had a bell-shape. It fit the theoretical Weibull distribution with shape parameter $\mathrm{c}=2.96$ for woody population and $\mathrm{c}=3.88$ for $P$. africana (Figure $3 \mathrm{c}$ and $3 \mathrm{~d}$ ). The results of the log-linear analysis indicate a good fit of the data to the Weibull distribution for both regions $(\mathrm{P}>0.05)$.
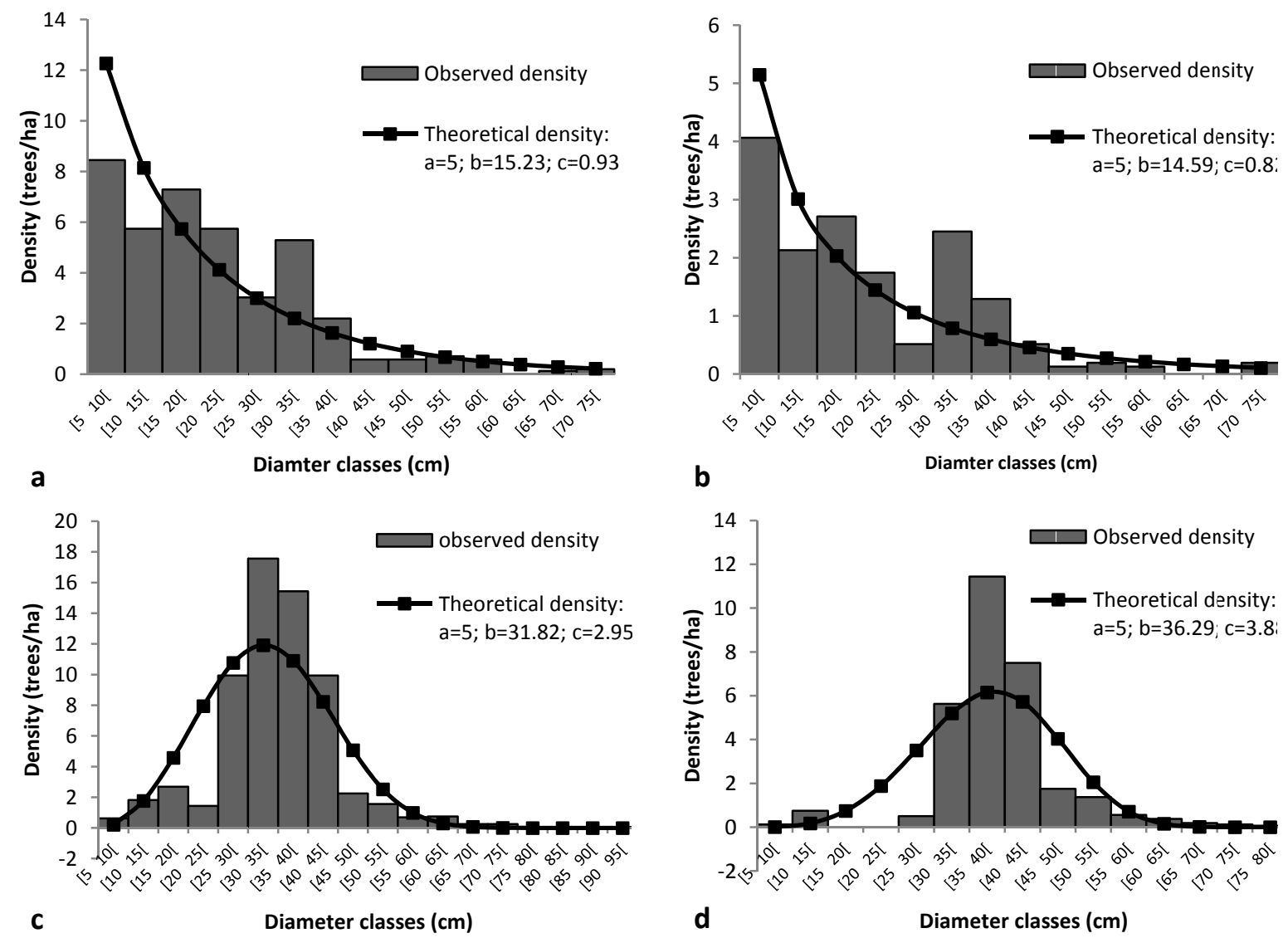

Figure 3. Structure of trunk diameter classes of (a) all woody species and (b) P. africana in the Maradi, and (c) all woody species and (d) P. africana (d) in Zinder 


\section{Discussion}

Prosopis africana was the most common species in the two regions. This is linked to the importance given to the species by the local population. In fact, the population would have favored the conservation of this species in previous years, while the climatic conditions were more favorable and the demographic pressure lowest. Indeed, in practice, farmers agree to keep a tree in their fields if they can have a crop production gain or if the crop yield decrease can be compensated by the economic gains due to the presence of the tree (Pierre et al., 1992). This could also explain the relatively low species diversity. The relatively high similarity between the two regions can be explained by climatic conditions and socioeconomic activities, including agricultural practices, which are essentially the same.

The distribution of trees in diameter classes with a shape of "J reversed" observed in Maradi (Figures 3a and 3b) with the shape parameter $\mathrm{c}=0.82(<1)$ for P. africana is characteristic of a fast regenerating stand. These results are similar to those found by others in vegetation study in Niger (Dan Guimbo et al., 2010; Abdourahamane et al., 2013; Boubacar et al., 2013).

The low proportion of $P$. africana trees in the large diameter classes in Maradi is due to a particularly important use of wood of this species. The wood of $P$. africana is strong and hard, so it is used as poles to support barns, houses, etc. and for mortars and pestles. For these uses, the wood of $P$. africana is preferred over the other species in this region (Laouali et al., 2014).

According to Ajonou et al. (2009), the bell shape distribution of trunk diameter reflects an unstable population characterized by an absence or very small proportion of individuals in one or more diameter classes. This is the situation in Zinder. The majority of $P$. africana trees were in the average diameter class $(30$ to $50 \mathrm{~cm})$, and individuals in the smaller and larger diameter classes were poorly represented. This could be explained by systematic cutting of large diameter trees (as in Maradi) and the vulnerability of small diameter trees to browsing animals and farmers seeking fodder. The regeneration of a natural stand is more certain if it has a lot of trees in the smaller diameter classes (Morou, 2010), so regeneration of P. africana is more threatened in Zinder than in Maradi.

The difference in diameter found between the two regions could be related to rainfall which is slightly higher in Zinder, although overall, the climatic conditions are essentially similar. The low regeneration of of $P$. africana compared with the total woody population could be explained by its relatively poor seed germination (Ahoton et al., 2009, Niang-Diop et al., 2010; Laouali et al., 2015). The fact that regeneration was better in Maradi than Zinder could be explained by the promotion of assisted natural regeneration by several research projects. This started to be adopted by farmers in the southern part of Maradi in the late 1980s, while in the Zinder region, the adoption started later (USAID, 2006; Larwanou et al., 2010).

Not enough of previous studies on this topic in the same area was an obstacle in the discussion of the results but makes this study more interesting. Based on this study, we can say that in the still extant $P$. africana stands, the regeneration rate of the species is lower than that of other species, especially in the Zinder region, even though development projects have promoted awareness campaigns and the practice of assisted natural regeneration. This confirms that $P$. africana is threatened with local extinction. Given these results and the socio-economic importance of this species, restoration operations through reforestation campaigns should be considered in areas with suitable habitat for the species. Growth and survival of trees are better for $P$. africana provenances from drier locations in Niger (Weber et al., 2008), and this probably is due to a higher root/shoot ratio in these provenances (Weber et al., 2015). The climate is becoming hotter and drier and with variable rainfall in the West African Sahel (Buontempo, 2010), so it would be advisable to use seed from drier locations for the reforestation campaigns. In addition, monitoring forestry extension services should provide technical assistance to rural communities for all steps in the reforestation process (seed collection, germination, planting, maintenance, monitoring and evaluation).

\section{References}

Abdourhamane, H., Morou, B., Rabiou, H., \& Mahamane, A. (2013). Caractéristiques floristiques, diversité et structure de la végétation ligneuse dans le Centre-Sud du Niger: cas du complexe des forêts classées de Dan Kada Dodo-Dan Gado. International Journal of Biological and Chemical Sciences, 7(3), 1048-1068. http://dx.doi.org/10.4314/ijbcs.v7i3.13

Agboola, D. A. (2004). Prosopis africana (Mimosaceae): stem, roots, and seeds in the economy of the savanna areas of Nigeria. Economic Botany, 58(Supplement), S34-S42. Retrieved from http://www.jstor.org/stable/4256906 
Ahoton, L. E., Adjakpa, J. B., M'po Ifonti M'po, \& Akpo E. L. (2009). Effet des prétraitements des semences sur la germination de Prosopis africana (Guill., Perrot. Et Rich.) Taub., (Césalpiniacées). Tropicultura, 27(4), 233-238. Retrieved from http://www.tropicultura.org/text/v27n4/233.pdf

Ajonou, K., Bellefontaine, R., \& Kokou, K. (2009). Les forêts claires du Parc national Oti-Kéran au Nord-Togo: structure, dynamique et impacts des modifications climatiques récentes. Sécheresse, 20(1), 1-10. http://dx.doi.org/10.1684/sec.2009.0217

Arbonnier, M. (2000). Arbres, arbustes et lianes des zones sèches d'Afrique de l'Ouest. CIRAD - MNHN - UICN, Montpellier (France).

Bellefontaine, R., Ferradous, A., Alifriqui, M., \& Monteuuis, O. (2010). Multiplication végétative de l'arganier, Argania spinosa, au Maroc : le projet John Goelet. Bois et Forêts des Tropiques, 304(2), 47-59. Retrieved from http://bft.cirad.fr/cd/BFT_304_47-59.pdf

Boubacar, M. M., Inoussa, M. M., Ambouta, J. M. K., Mahamane, A., Jorgen, A. A., Harissou, Y., \& Rabiou, H. (2013). Caractérisation de la végétation ligneuse et des organisations pelliculaires de surface des agroécosystèmes à différents stades de dégradation de la Commune rurale de Simiri (Niger). Int. J. Biol. Chem. Sci., 7(5), 1963-1975. http://dx.doi.org/10.4314/ijbcs.v7i5.15

Buontempo, C. (2010). Sahelian climate: past, current, projections. Met Office Hadley Centre, Devon. Retrieved from http://www.oecd.org/swac/publications/47092928.pdf

Curtis, J. T., \& McIntosh, R. P. (1951). An upland forest continuum in the prairie-forest border region of Wisconsin. Ecology, 32(3), 476-496. http://dx.doi.org/10.2307/1931725

Dan Guimbo, I., Mahamane, A., \& Ambouta, J. M. K. (2010). Peuplement des parcs à Neocarya macrophylla (Sabine) Prance et à Vitellaria paradoxa (Gaertn. C.F.) dans le sud-ouest nigérien : diversité, structure et régénération. Int. J. Biol. Chem. Sci., 4(5), 1706-1720. http://dx.doi.org/10.4314/ijbcs.v4i5.65568

Endress, B. A., Gorchov, D. L., \& Berry, E. J. (2006). Sustainability of a non-timber forest product: effect of alternative leaf harvest practices over 6 years on yield and demography of the palm Chamaedorea radicalis. Forest Ecology and Management, 234, 181-191. http://dx.doi.org/10.1016/j.foreco.2006.07.020

Faye, M. D., Weber, J. C., Abasse, T. A., Boureima, M., Larwanou, M., Bationo, A. B., ... Sonogo Diaité, D. (2011). Farmers' preferences for tree functions and species in the West African Sahel. For. Trees and Livelihoods, 20, 113-136. http://dx.doi.org/10.1080/14728028.2011.9756702

INS. (2014). Recensement général de la population et de l'habitat, 2012. Répertoire national des localités. Institut National de la Statistique, Niger.

Laouali, A., Dan Guimbo, I., Larwanou, M., Inoussa, M. M., \& Mahamane A. (2014). Utilisation de Prosopis africana (G. et Perr.) Taub. dans le sud du département d'Aguié au Niger: les différentes formes et leur importance. Int. J. Biol. Chem. Sci., 8(3), 1065-1074. http://dx.doi.org/10.4314/ijbcs.v8i3.20

Laouali, A., Dan Guimbo, I., Youchaou, A., Rabiou, H., \& Mahamane A. (2015a). Etude de la germination de la graine et suivi de la croissance en pépinière de Prosopis africana (G. et Perr.) Taub., espèce menacée de disparition au Niger. Annales de l'Université Abdou Moumouni de Niamey, Tome XVIII-A, 1-12.

Larwanou, M. (1994). Potentials of Prosopis africana (G. et Perr.) Taub leaf litter for soil nutrient enhancement and crop development. M.Sc thesis. Department of Forest resources Management, University of Ibadan.

Larwanou, M., Moustapha, A. M., Rabé, M. L., \& Dan Guimbo, I. (2012). Contribution de la Régénération Naturelle Assistée des ligneux dans l'approvisionnement en bois des ménages dans le département de Magaria (Niger). Int. J. Biol. Chem. Sci., 6(1), 24-36. http://dx.doi.org/10.4314/ijbcs.v6i1.3

Larwanou, M., Oumarou, I., Laura, S., Dan Guimbo, I., \& Eyog-Matig, O. (2010). Pratiques sylvicoles et culturales dans les parcs agroforestiers suivant un gradient pluviométrique nord-sud dans la région de Maradi au Niger. Tropicultura, 28(2), 115-122. Retrieved from http://www.tropicultura.org/text/v28n2/115.pdf

Morou, B. (2010). Impacts de l'occupation des sols sur l'habitat de la girafe au Niger et enjeux pour la sauvegarde du dernier troupeau de girafes de l'Afrique de l'Ouest. Thèse de Doctorat Unique, Université Abdou Moumouni de Niamey.

Niang-Diop, F., Sambou, B., \& Lykke, A. M. (2010). Contraintes de régénération naturelle de Prosopis africana: facteurs affectant la germination des graines. Int. J. Biol. Chem. Sci., 4(5), 1693-1705. http://dx.doi.org/10.4314/ijbcs.v4i5.65578 
Ouédraogo, A., Thiombiano, A., Hahn-hadjali, K., \& Guinko, S. (2006). Régénération sexuée de Boswellia dalzielii Hutch., un arbre médicinal de grande valeur au Burkina-Faso. Bois et forêts des Tropiques, 289(3), 41-48. Retrieved from http://bft.revuesonline.com/gratuit/BFT_PDF_289_41-48.pdf

Pierre, G., Waechter, P., \& Yachinovsky, A. (1992). Environnement et développement rural. Guide pour la gestion des ressources naturelles. Editions Frisson-Roche, Agence de Coopération culturelle et technique, Ministère de la coopération et du Développement, Paris.

Rondeux, J. (1999). La Mesure des arbres et des peuplements forestiers (2nd ed.). Les presses agronomiques de Gembloux.

Saadou, M. (1990). La végétation des milieux drainés nigériens à l'Est du fleuve Niger. Thèse de Doctorat ès Sciences Naturelles. Université de Niamey.

Sanogo, S., Sacandé, M., Van Damme, P., \& N'Diaye, I. (2013). Caractérisation, germination et conservation des graines de Carapa procera DC. (Meliaceae), une espèce utile en santé humaine et animale. Biotechnologie, Agronomie, Société et Environnement, 17(2), 321-331. Retrieved from http://www.pressesagro.be/base/text/v17n2/321.pdf

Shannon, C. E., \& Weaver, W. (1949). The mathematical theory of communication. Urbana, Univ. Illinois Press.

Sørensen, T. (1948). A method of establishing groups of equal amplitude in plant sociology based on similarity of species and its application to analyses of the vegetation on Danish commons. Biol. Skr., 5, 1-34.

Sotelo Montes, C., \& Weber, J. C. (2009). Genetic variation in wood density and correlations with tree growth in Prosopis africana from Burkina Faso and Niger. Ann. For. Sci., 66, 713. http://dx.doi.org/10.1051/forest/2009060

Sotelo Montes, C., Silva, D. A., Garcia, R. A., Muñiz, G. I. B., \& Weber, J. C. (2011). Calorific value of Prosopis africana and Balanites aegyptiaca wood: relationships with tree growth, wood density and rainfall gradients in the West African Sahel. Biomass and Bioenergy, 35, 346-353. http://dx.doi.org/10.1016/j.biombioe.2010.08.058

USAID. (2006). Etude de la régénération Naturelle Assistée dans la Région de Zinder (Niger). Une première exploration d'un phénomène Rectaculaire. http://www.gtu.dk/Niger_Study_2006_re-greening.pdf

Weber, J. C., Larwanou, M., Abasse, T. A., \& Kalinganire, A. (2008). Growth and survival of Prosopis africana provenances tested in Niger and related to rainfall gradients in the West African Sahel. For. Ecol. Manage., 256, 585-592. http://dx.doi.org/10.1016/j.foreco.2008.05.004

Weber, J. C., Sotelo Montes, C., Kalinganire, A., Abasse, T., \& Larwanou, M. (2015) Genetic variation and clines in growth and survival of Prosopis africana from Burkina Faso and Niger: comparing results and conclusions from a nursery test and a long-term field test in Niger. Euphytica, 205, 809-821. http://dx.doi.org/10.1007/s10681-015-1413-4

\section{Copyrights}

Copyright for this article is retained by the author(s), with first publication rights granted to the journal.

This is an open-access article distributed under the terms and conditions of the Creative Commons Attribution license (http://creativecommons.org/licenses/by/3.0/). 